\title{
Sprawozdanie z XIII Ogólnopolskiej konferencji z cyklu „Ekologia humanistyczna” pt. „Przyroda wyzwaniem dla kultury. Społeczności lokalne wobec obszarów chronionych" (Warszawa, 16-17.10.2019)
}

\author{
Report on $13^{\text {th }}$ Conference in "Humanistic Ecology" Series: "Nature as a Challenge for Culture. \\ Local Communities Towards Protected Areas" (Warsaw 16-17 October 2019)
}

\author{
Ryszard F. Sadowski \\ Centrum Ekologii i Ekofilozofii, Uniwersytet Kardynała Stefana Wyszyńskiego w Warszawie \\ ORCID: https://www.orcid.org/0000-0002-5452-2168・r.sadowski@uksw.edu.pl
}

Instytut Ekologii i Bioetyki w Uniwersytecie Kardynała Stefana Wyszyńskiego w Warszawie od roku 2006 systematycznie organizuje coroczne konferencje na temat kryzysu środowiskowego. Z inicjatywy ks. prof. Józefa Marcelego Dołęgi we współpracy ze Wszechnicą Mazurską w Olecku oraz Uniwersytetem Witolda Wielkiego w Kownie zorganizowano w latach 2006-2016 łącznie 10 konferencji z cyklu „Ekologia społeczna”. W roku 2018 władze Instytutu podjęły decyzję o kontynuacji przedsięwzięcia pod zmienionym tytułem z zachowaniem jednak numeracji kolejnych konferencji. W tym samym roku zorganizowano XI Ogólnopolską konferencję z nowego cyklu „Ekologia humanistyczna” pt. „Las dla człowieka - człowiek dla lasu".

Nowy cykl konferencji odzwierciedla zakres badań prowadzonych w Instytucie Ekologii i Bioetyki UKSW, który w październiku 2019 r. został przekształcony w Centrum Ekologii i Ekofilozofii (CEiE). Prowadzone tu badania podejmują zarówno humanistyczne aspekty szeroko rozumianej kwestii ekologicznej, jak i przyrodoznawcze badania nad tą kwestią oraz uwzględniają antropologiczne, filozoficzne, etyczne, edukacyjne i prawne jej aspekty. Badania te mają więc na celu ukazanie wzajemnych powiązań humanistyki z przyrodoznawstwem w pracach nad opisem, analizą i prognozowaniem zagrożeń środowiskowych.

Potwierdzeniem interdyscyplinarnego podejścia do kwestii ekologicznej w CEiE jest tematyka podejmowana w ramach kolejnych konferencji z cyklu „Ekologia humanistyczna”. I tak, 15 maja 2019 r. odbyła się na UKSW XII Międzynarodowa konferencja pt. „The Church towards Ecological Crisis. On the $30^{\text {th }}$ Anniversary of Polish Bishops' Pastoral Letter on Environmental Protection", a 16-17 października 2019 r. XIII Ogólnopolska konferencja pt. „Przyroda wyzwaniem dla kultury. Społeczności lokalne wobec obszarów chronionych". Konferencja ta została zorganizowana przez Centrum Ekologii i Ekofilozofii UKSW przy współpracy Instytutu Badawczego Leśnictwa (IBL) i Kampinoskiego Parku Narodowego (KPN). 
Patronami honorowymi konferencji byli: Senacka Komisja Środowiska, Ministerstwo Środowiska, Urząd Marszałkowski Województwa Mazowieckiego, Lasy Państwowe oraz Polskie Towarzystwo Leśne. Patronat medialny sprawował Klub Publicystów Ochrony Środowiska EKOS. W ramach konferencji zaprezentowano 27 referatów. Prelegenci reprezentowali 17 polskich ośrodków naukowo-badawczych oraz 8 innych instytucji (parki narodowe, fundacje, przedsiębiorstwa, muzea, szkoły i media). W sesji referatowej na Uniwersytecie Kardynała Stefana Wyszyńskiego w Warszawie uczestniczyło ok. 115 osób, natomiast w sesji terenowej w Kampinoskim Parku Narodowym wzięło udział 25 uczestników.

Pierwszy dzień konferencji miał charakter sesji referatowej, która odbyła się na terenie kampusu UKSW przy ul. Wóycickiego 1/3 w Warszawie. Obrady przebiegały w równoległych sekcjach tematycznych: przyrodniczo-filozoficznej, społeczno-prawnej i edukacyjnej. Różnorodność i wysoki poziom merytoryczny wystąpień sprawił, że uczestnicy z jednej strony z łatwością odnajdywali interesujące ich tematy, $\mathrm{z}$ drugiej zaś strony z trudnością dokonywali wyboru referatu, ze względu na równie interesujące propozycje prezentowane w tym samym czasie w równolegle odbywających się sesjach. Nie sposób w kilku zdaniach streścić i podsumować tak wielu i tak różnorodnych wystąpień, dlatego osoby zainteresowane odsyłamy do publikacji pokonferencyjnej pt. „Przyroda wyzwaniem dla kultury. Społeczności lokalne wobec obszarów chronionych" (Instytut Badawczy Leśnictwa 2020).

Drugi dzień konferencji miał charakter sesji terenowej, która odbywała się w Kampinoskim Parku Narodowym. Jej celem było: pokazanie funkcjonowania parku narodowego w warunkach silnej antropopresji; zaangażowanie społeczności lokalnej w zarządzanie obszarem parku; przeciwdziałanie i rozwiązywanie konfliktów; edukacja ekologiczna oraz udostępnianie obszaru KPN. Program wyprawy obejmował wizytę w siedzibie Kampinoskiego Parku Narodowego w Izabelinie, skąd - po prezentacji na temat osiągnięć i wyzwań, przed jakimi staje zarząd KPN - uczestnicy udali się do wysuniętych na zachód części parku, obserwując unikalne wydmy śródlądowe, torfowiska, łąki niżowe i olsy. Wyprawa zakończyła się w Ośrodku Dydaktyczno-Muzealnym Kampinoskiego Parku Narodowego w Granicy, gdzie - po zapoznaniu się z jego ofertą dydaktyczną - przy ognisku podsumowano całość konferencji. 